\title{
Antrenörlerde Duygusal Emek ve Tükenmişlik İlişkisinin İncelenmesi
}

\author{
DOI: 10.26466/opus.515620 \\ * \\ Sevim Güllü̈-Süleyman Şahin ${ }^{* *}$ \\ * İstanbul Üniversitesi-Cerrahpaşa, Spor Bilimleri Fakültesi, Spor Yönetim Bilimleri Anabilim Dalı, \\ İstanbul/Türkiye \\ E-Posta: sevim.gullu@istanbul.edu.tr \\ ORCID: 0000-0002-8027-8891 \\ **Uludağ Üniversitesi, Spor Bilimleri Fakültesi, Beden Eğitimi ve Spor Öğretmenliği Anabilim \\ Dalı, Bursa/Türkiye

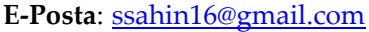 \\ ORCID: $0000-0003-2790-4483$
}

Öz

Bu araştırmanın amacı antrenörlerin duygusal emek ile tükenmişlik arasındaki ilişki düzeyini incelemektedir. Araştırma tekniği olarak nicel araştırma yöntemlerinden betimsel ve ilişkisel tarama tekniğgi kullanılmıştır. Çalışma grubunu, seçkisiz olmayan örnekleme yöntemlerinden kolayda örnekleme yöntemi ile seçilen farkl illerin Gençlik ve Spor İl Müdürlü̈̆̈̈̈nde görev yapan 89'u kadın, 271'i erkek toplam 360 olimpik spor branş antrenörü oluşturmaktadır. Katılımcılara demografik bilgiler sorulmuştur. Ayrıca, bulgulara ulaşmak için Duygusal Emek Ölçeğgi ile Tükenmişlik Ölçeği kullanılmıştır. Yüzde, frekans, t-testi, Korelasyon Analizi yapılmıştır. Bulgulardan elde edilen sonuçlara göre; antrenörler en çok doğal duygular ile hareket etmekte, bunu derinden rol yapma izlemektedir. Sonuncu sirada ise yüzeysel davranış yer almaktadır. Tükenmişlik alt boyutları incelendiğinde duyarsızlaşma alt boyutu en düşük ortalamaya sahiptir, bunu duygusal tükenme ile kişisel başarıda düşme alt boyutlarmın izlemektedir. Derinden rol yapma davranışı tükenmişlik ile ilişkili değildir; yüzeysel rol yapma davranışı düşük düzeyde de olsa duyarsızlaşma alt boyutu ile pozitif yönde ilişkilidir. Medeni durum değiş̧keninin derinden rol yapma ve doğal duygular üzerinde anlamlı fark yarattığı, farklılığın ise evli katılımcilar lehine olduğu görülmektedir. Sonuç olarak duygusal emek ve tükenmişlik arasında ilişki olduğu görülmektedir.

Anahtar Kelimeler: Duygusal emek, tükenmişlik, antrenör 


\title{
Analysis of the Correlation Between Emotional Labour and Burnout in Coaches
}

\begin{abstract}
The goal of this research is to analyze the correlation level between emotional labour and burnout of coaches. Descriptive survey and correlation survey models which are among the qualitative research models were used in the research. The study group involved 89 female and 271 male olympic sport branches coaches (total 360) serving in the Youth and Sports Directorates of different cities, who were selected using the convenience sampling method which is one of the non-random sampling methods. Research participants were asked demographical questions. Also the Emotional Labour scale and the Burnout Scale were used. Percentage, frequency, $t$-test and Correlation Analysis were performed. Level of significance was regarded to be $p<0.05$. According to the findings, actions of coaches are generally driven by their natural emotions. This is followed by deep role playing. Superficial behaviour comes last. Analysis of the sub-dimensions of the concept of burnout shows that, sub-dimension of desensitization has the lowest average, it is followed by the sub-dimensions of emotional burnout and decrease in the level of personal success. Deep role playing is not related with burnout. Superficial role playing is in positive relationship with the sub-dimension of desensitization, even though it is at a low level. It is also observed that the variable of marital status creates a significant difference on deep role playing and natural emotions in favour of participants who are married. In conclusion, it is seen that there is a correlation between emotional labour and burnout.
\end{abstract}

Keywords: Emotional labour, burnout, coach 


\section{Giriş}

Her mesleğin kendine özgü özellikleri vardır ve o mesleği icra eden bireylerin duygu durumları/davranışları genel olarak birbirine benzer özellikler taşır. Öğretmenin öğrencilerinin akademik başarılarındaki doğrudan etkisi gibi antrenörlük mesleği de sporcunun sporculuk başarısında doğrudan etkisi olan özel mesleklerdendir. Mesleğinin gereklerini yerine getiren, meslek ahlakı gelişmiş öğretmenler özveri ile çalışırlar ve özellikle küçük yaşlardaki öğrencilerin karakter oluşumlarında yönlendirici rol oynarlar; buna benzer şekilde antrenör de sporcusunun olumlu alışkanlıklar kazanmasında ve hatta bunların karakter özelliği haline gelmesinde önemli pay sahibidirler. Antrenörlük mesleğinin önemli bir diğer özelliği de, sporcularla zaman zaman çok uzun saatler zaman geçirmeleri, müsabakalar için beraber kısa/uzun seyahatler yapmaları, diğer deyişle belli bir mesai mefhumu olmadan çalışmalarıdır. Böyle bir dinamizm ise antrenörün sporcularını birçok yönleriyle tanıma fırsatı sağlar. Sporcusunun güçlü/zayıf yönlerini iyi gözlemleyen iyi bir antrenör yerinde ve zamanında bulunduğu müdahaleler ile onların birçok yönüyle gelişimine de katkı sağlayacaktır. Bu sürecin gereklerinden birisi duygusal emek harcanmasıdır. Sürecin, mesleği icra edenlerce en önemli sonuçlarından birisi ise tükenmişlik yaşama ihtimalinin olmasıdır. Bu araştırmada çeşitli spor branş antrenörlerinin duygusal emek ile tükenmişlik düzeyleri incelenecektir.

\section{Duygusal Emek}

Duygusal emek, çalışanın örgüt tarafından istenilen duyguları sergilemesi olarak tanımlanır (Yürür ve Ünlü, 2011). Örgütler çalışanlarından doğru davranışların yanı sıra doğru duygusal tepkileri göstermelerini beklerler. Özellikle hizmet sektöründe çalışanlar için önemli bir kavramdır İşi gereği insanlarla birebir iletişimde olan çalışanların, duygusal tepkilerini örgüt amaçlarına uygun ve örgüt için kabul edilebilir şekle sokmaları için harcadıkları çabadır (Oral ve Köse, 2011).

Duygusal emek kavramı üç alt boyutta incelenmektedir. Yüzeysel rol yapma; kişinin, gerçekte hissetmediği duyguları hissediyormuş gibi yapmasıdır (Kaplan ve Ulutaş, 2016). Bireyler gerçek duygularını değiştirmez 
ama duygu gösterimlerini kontrol eder ve kendisinden beklenen şekilde tepki verirler, diğer deyişle gerçekte hissettikleri duygularını değiştirmezler, burada amaç örgütün kendisinden istediğini yerine getirmektir (Grandey, 2003; akt: Oral ve Köse, 2011). Yüzeysel davranışta kişinin duyguları ile davranışları birbiri ile uyum içerisinde değildir. Kişinin hissettikleri ile gösterdiği duygular birbirinden çok farklıdır. Kişi, göstermek zorunda olduğu davranışa odaklanır ve gerçek duygularını belli etmemeye çalışır (Grandey, 2003, akt: Tunç vd:2014). Kendi duygularını bastırıp örgütün istediği şekilde davranması (Akdu ve Akdu, 2016), bir nevi sahte davranmak ve rol yapmaktır (Güler ve Marşap, 2018). Derinden rol yapma; çalışanın, kendinden istenen duyguyu, yüzeysel rol yapma kavramından farklı olarak, gerçekten hissetmeye çalışması (Kaplan ve Ulutaş, 2016) ve yalnızca davranışların değil duyguların da davranış kurallarına uyumlu hale getirilmesidir (Oral ve Köse, 2011). Kişinin göstermek istediği duygular ile göstermek zorunda olduğu duygular birbirinden farklı olsa bile kişi öncelikle duygularını değiştirmek ve koşullara uymak yolunu seçer, böylece duyguları ile davranışları arasında doğal bir uyum oluşur (Ashforth ve Humphrey, 1993; akt: Tunç vd, 2014). Doğal duygular; çalışanın çok az duygusal emek harcayarak (Tunç vd., 2014); bir zorunluluk hissetmeden, içinden geldiği gibi duygularını dişa yansıtmasıdır (Beğenirbaş ve Yalçın, 2012).

Yüzeysel rol yapma, derinden rol yapma ve doğal duygular alt boyutları arasındaki temel fark içselleştirme düzeyidir. Yüzeysel davranış, içselleştirilmemiş davranışları içerir. Derinden rol yapma boyutunda içselleştirme düzeyi yüzeysel davranışa göre daha fazla ancak doğal davranışa göre daha azdır (Yılmaz vd, 2015). Örgüt ve müşteri açısından avantajlı olan bazı şeyler görevi yerine getiren kişi açısından dezavantajlı olabilmektedir (Yürür ve Ünlü, 2011). Hizmet sektöründe memnun edilmesi beklenilen müşteriler için sergilenmesi istenen belli davranış kalıpları vardır. Bunu gerçekleştirebilmek için ise önemli ölçüde çaba harcamak zorunda kalmaktadır. Harcanan çaba sonunda karşı tarafın memnuniyetsizliği, çalışanın duygusal iniş ve çıkışlar ile pozitif/negatif duygu değişimleri yaşamasina neden olurken, duygusal anlamda tüm sermayesini tüketmesi sonucunu ortaya çıkarabilmektedir (Mengenci, 2015). 


\section{Tükenmişlik}

Bireyin, olumsuz koşullar ve yaşanmışlıklar sonucu enerji kaynaklarının azaldığını hissetmesidir. Üç boyutta incelenmektedir. Duygusal tükenme; tükenmişlik sendromunun en temel bileşenidir. Kişinin hem fiziksel hem duygusal açıdan bitkin olması (Yılmaz vd, 2015), kişinin duygusal kaynaklarının aşırı zorlanmış ve bitmiş olması durumudur. Duyarsızlaşma; hizmet alanlara karşı negatif, duygusuz veya aşırı tepkili olmayı ifade eden bir kavramdır. Kişisel başarıda düşme hissi; kişinin işi ile ilgili yeterlilik ve verimliliğinin düştügüune inanmasıdır (Kaplan ve Ulutaş, 2016).

Tükenmişlik süreci kişinin duygusal kaynaklarını tüketen iş ile ilgili stres kaynaklarına bir tepki olarak ortaya çıkar ve ilk olarak duygusal tükenme ile başlar. Çalışan duygusal tükenme ile beraber, başa çıkma stratejisi olarak diğerleri ile olan ilişkilerini kesme ve araya psikolojik mesafe koyma yolunu seçer. Duyarsızlaşma oluştuğunda ise birey mevcut durumu ile örgüt beklentileri arasındaki uyumsuzluğu fark eder, bu da kişisel başarıda düşme hissine neden olur (Lewin ve Sager, 2007; akt: Kaplan ve Ulutaş, 2016).

Duygusal emek, duyguların yönetimi ve buna göre davranmak olduğu için, konuyla ilgili araştırmalar daha çok duygusal emek ile çalışanın tutum ve davranışları arasındaki ilişkiye odaklanmıştır (Yılmaz vd, 2015). Duygusal emek harcanması; örgütte verimlilik artışı veya hizmet kalitesinde yükselme, müşteri memnuniyetinde artış gibi olumlu çıtılar sağlasa da çalışanların iş doyumsuzluğu, tükenmişlik, psikolojik ve fizyolojik rahatsızlıklar ve yabancılaşma yaşamalarına neden olabilmektedir (Oral ve Köse, 2011). Tükenmişlik, duygusal emeğin en belirgin (Eroğlu, 2014) ve en önemli (Polatcı ve Özyer, 2015) sonuçlarından biri olarak görülmektedir.

Uzun süre gerçek hislerinden farklı davranmanın kişiyi yalnızca gerçek duygularından koparmayacağını, aynı zamanda diğer insanların duygularını anlamasını da zorlaştırabileceği iddia edilmiştir. Bu durum, tükenmişliğin duyarsızlaşma boyutu ile ilişkilidir. Bir çalışan eğer, duygusal gösterimlerinin istenen sonuca ulaşmayı sağlamadığına inanıyorsa, bunun devaminda büyük ihtimalle kişisel başarıda düşme hissi yaşayacaktır. Dolayısıyla yüzeysel davranışın, tükenmişliğin üç 
boyutuyla da ilişkili olması beklenmektedir. Çalışanların derin davranış performansının etkili olduğu durumlarda, duygusal emek gerektiren işleri yapması başarı hissi ile de sonuçlanabilir ve duygusal çelişkiyi azaltmanın bir yolu da olabilir. Derin davranışın duygusal çelişkinin yarattığ gerilimi en aza indirmesi nedeniyle derin davranışın duygusal tükenme ile ilişkili olmadığı söylenebilir (Brotheridge ve Grandey, 2002; akt: Eroğlu, 2014).

Öğretmenlik mesleği, doğası gereği, doğrudan insan ile ilgili bir meslektir. Bu nedenle, diğer tüm insan-yoğun mesleklerde olduğu gibi, duyguların düzenlenmesini gerektirir. Duygusal emek, öğretmenlerden aynı zamanda profesyonel bir gereklilik olarak beklenir. Öğretme; bireysel, sosyal, kültürel, bilimsel ve teknolojik yönden eğitimi içerir. Öğretmenler öğrenciler için rol model olurlar, onlara rehberlik ederler, onlara çeşitli tutum ve değerler kazandırırlar. Bunları yerine getirirken bilinçli bir çaba sarfetmeleri gerekir. Duygularını düzenlemeleri gerekliliği onların tükenmişlik yaşamaları gibi bir sonuç doğurabilir (Yılmaz vd, 2015). Antrenörlük mesleği de öğretmenlik mesleğine benzer şekilde; sporcularının spor kariyerlerinde ve başarılarında, onların çeşitli olumlu alışkanlıkları kazanmalarında, hatta fair play'e uygun davranışlarında etkili birer figürdürler. Bir antrenörün sporcuları üzerinde bu derece etkili olması, onların duygusal emek sarf ettiği şeklinde değerlendirilebilir.

Yukarıdaki literatür bilgileri doğrultusunda; araştırmamızda antrenörlerin duygusal emek ile tükenmişlik düzeyleri ile bu iki değişken arasındaki ilişki düzeyini incelemek amaçlanmıştır.

\section{YÖNTEM}

\section{Araştırmanın modeli}

Bu çalışmada araştırma tekniği olarak nicel araştırma yöntemlerinden betimsel ve ilişkisel tarama tekniği kullanılmıştır.

\section{Çalışma Grubu}

Çalışma grubunu, seçkisiz olmayan örnekleme yöntemlerinden kolayda örnekleme yöntemi ile seçilen; Antalya, Bursa, Diyarbakır, Elazığ, Erzurum, İzmir, Kayseri, Konya, Manisa, Rize, Trabzon ve Van illerinin 
Gençlik ve Spor İl Müdürlüğü bünyesinde görev yapan 89'u kadın, 271'i erkek olmak üzere toplamda 360 olimpik spor branş antrenörü oluşturmaktadır.

\section{Veri toplama araci}

Duygusal Emek Ölçeği: Ölçek, Diefendorff vd (2005), Grandey (2003) ve Kruml ve Geddes (2000) tarafından geliştirilmiştir. Basım ve Beğenirbaş (2012) ise ölçeğin bazı maddelerini alarak Türkçe' ye uyarlamış ve geçerlik-güvenirlik çalışmasını yaparak literatüre kazandırmışlardır. Yüzeysel rol yapma, derinden rol yapma ve doğal duygular olmak üzere üç alt boyuttan ve toplamda 16 ifadeden oluşmaktadır. 1 hiçbir zaman, 5 her zaman olmak üzere $5^{\prime}$ li likert tipte yapılandırılmıştır.

Tükenmişlik Ölçeği: Maslach ve Jackson (1981) tarafından geliştirilmiştir, Ergin (1992) Türkçeye uyarlamıştır, 22 sorudan ve üç boyuttan oluşmaktadır. Sevim (2011)' in çalışmasından birebir alınarak kullanılmıştır. Ölçek 22 madde ve duygusal tükenme, duyarsızlaşma ve kişisel başarıda düşme hissi olmak üzere 3 alt boyuttan oluşmaktadır.

Tablo 1. Ölçek puan değerleri

\begin{tabular}{|c|c|c|c|c|c|}
\hline & Alt Boyutlar & $\mathrm{n}$ & Ort & Ss & $\begin{array}{l}\text { Mevcut Araştırma } \\
\text { Güvenirlik } \\
\text { Katsayıları } \\
\text { (Cronbach } \\
\text { Alpha) }\end{array}$ \\
\hline \multirow{3}{*}{ 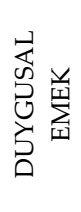 } & $\begin{array}{l}\text { Yüzeysel Rol } \\
\text { Yapma }\end{array}$ & $\begin{array}{c}6 \\
\text { (1-6. ifadeler) }\end{array}$ & 2,150 & ,946 & 830 \\
\hline & $\begin{array}{l}\text { Derinden Rol } \\
\text { Yapma }\end{array}$ & $\begin{array}{c}4 \\
\text { (7-10. ifadeler) }\end{array}$ & 3,783 & 1,000 & 853, \\
\hline & $\begin{array}{l}\text { Doğal Duygu- } \\
\text { lar }\end{array}$ & $\begin{array}{c}3 \\
\text { (11-13. ifadeler) }\end{array}$ & 4,262 & ,774 & 760 \\
\hline \multirow{3}{*}{ 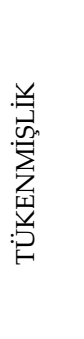 } & $\begin{array}{l}\text { Duygusal Tü- } \\
\text { kenme }\end{array}$ & $\begin{array}{c}9 \\
(1,2,3,6,8,13,14,16 \text { ve } 20 . \\
\text { İfdeler })\end{array}$ & 2,104 & ,706 & ,775 \\
\hline & Duyarsızlaşma & $\begin{array}{c}5 \\
(5,10,11,15 \text { ve } 22 . \text { İfadeler })\end{array}$ & 1,928 & 819 & 735, \\
\hline & $\begin{array}{l}\text { Kişisel Başarıda } \\
\text { Düşme Hissi }\end{array}$ & $\begin{array}{c}(4,7,9,12,17,18,19 \text { ve } 21 . \\
\text { ifadeler) } \\
\text { (tamamı ters kod- } \\
\text { lanmiştır) }\end{array}$ & 3,679 & ,776 & 780 \\
\hline
\end{tabular}


Ölçeklerin alt boyutlarına ilişkin bilgiler Tablo 1' de sunulmuştur. Tablo 1' de toplanan verilerden elde edilen sonuçlara bakıldığında, hem Duygusal Emek ölçeği alt boyutları hem de Tükenmişlik Ölçeği alt boyutları için güvenirlik katsayıları (cronbach alpha) yüksek sayılabilecek ve/veya kabul edilen değerlerin üzerindedir.

\section{Verilerin analizi}

Elde edilen verilerin değerlendirilmesi için; SPSS 20 yardımıyla istatistiki analiz yapılmıştır. Araştırmaya katılanların demografik bilgilerinin dağılımlarının belirlenmesi için tanımlayıcı istatistik yöntemleri olan yüzde (\%) ve frekans (f) yöntemleri kullanılmıştır. Verilerin normal bir dağılıma sahip olduğu görüldükten sonra anlamlı farklılıkların belirlenmesi için iki faktörlü değişkenler için t testi yapılmıştır. Anlamlılık düzeyi ise $\mathrm{p}<0,05$ olarak kabul edilmiştir. Ayrıca duygusal emek ile tükenmişlik alt boyutları arasındaki ilişkilerin tespitinde Pearson Korelasyon analizi kullanılmıştır.

\section{Bulgular}

Katılımcıların demografik bilgileri aşağıdaki tabloda sunulmuştur.

Tablo 2. Katılımcıların Demografik Özellikleri

\begin{tabular}{lccc}
\hline & & $\mathrm{n}$ & $\%$ \\
\hline \multirow{3}{*}{ Cinsiyet } & Kadın & 89 & 24,7 \\
& Erkek & 271 & 75,3 \\
\multirow{3}{*}{ Medeni Durum } & Toplam & 360 & 100,0 \\
& Bekar & 119 & 33,1 \\
& Evli & 241 & 66,9 \\
& Toplam & 360 & 100,0 \\
Eğitim Düzeyi & Lise & 46 & 12,8 \\
& Önlisans & 15 & 4,2 \\
& Lisans & 269 & 74,7 \\
Antrenörlük BranşTürü & Lisansüstü & 30 & 8,3 \\
& Toplam & 360 & 100,0 \\
Kaç Yıldır Antrenörlük Yapıor & Takım sporları & 136 & 37,8 \\
& Bireysel sporlar & 224 & 62,2 \\
& Toplam & 360 & 100,0 \\
& $1-5$ yıl & 98 & 27,2 \\
& $6-10$ yıl & 142 & 39,4 \\
\hline
\end{tabular}




\begin{tabular}{cccc}
\hline $11-15$ yıl & 73 & 20,3 \\
$16-20$ yıl & 31 & 8,6 \\
21 yll ve üzeri & 16 & 4,4 \\
Toplam & 360 & 100,0 \\
\hline
\end{tabular}

Tablo 2' ye göre katılımcıların 89' u (\%24,7) kadın, 271' i (\%75,3) erkek; $119^{\prime}$ u bekar (\%33,1), 241' i $(\% 66,9)$ evli; $46^{\prime}$ s1 $(\% 12,8)$ lise, $15^{\prime}$ i $(\% 4,2)$ önlisans, 269' u lisans (\%74,7), 30' u lisansüstü (\%8,3); 136' s1 (\%37,8) takım sporlar1, 224' ü $(\% 62,2)$ bireysel sporlar antrenörü; 98' si (\%27,2) 1-5 yıldır, 142 ' si (\%39,4) 6-10 yıldır, 73' ü (\%20,3) 11-15 yıldır, 31' i (\%8,6) 16-20 yıldır, $16^{\prime}$ sı $(\% 4,4) 21$ ve üzeri yıldır antrenörlük yapmaktadır. Katılımcıların yaş ortalaması $35,57^{\prime}$ dir.

Tablo 3. Medeni Durum Değişkenine Göre Ölçek Alt Boyutlarn t Testi Sonucu

\begin{tabular}{lcccccc}
\hline \multicolumn{1}{c}{ Medeni Durum } & & $\mathrm{n}$ & Ort & Ss & $\mathrm{t}$ & $\mathrm{p}$ \\
\hline \multirow{2}{*}{ Yüzeysel Rol Yapma } & Bekâr & 119 & 2,182 & 0,959 & \multirow{2}{*}{0,445} & \multirow{2}{*}{0,657} \\
& Evli & 241 & 2,135 & 0,943 & & \\
Derinden Rol Yapma & Bekar & 119 & 3,613 & 1,049 & $-2,276$ & $\mathbf{0 , 0 2 3}$ \\
& Evli & 241 & 3,867 & 0,967 & & \\
Doğal Duygular & Bekar & 119 & 3,980 & 0,933 & $-0,508$ & $\mathbf{0 , 0 0 0}$ \\
& Evli & 241 & 4,401 & 0,641 & & \\
Duygusal Tükenme & Bekar & 119 & 2,120 & 0,703 & 0,280 & 0,779 \\
& Evli & 241 & 2,097 & 0,710 & & \\
Duyarsızlaşma & Bekar & 119 & 1,923 & 0,772 & $-0,977$ & 0,329 \\
Kişisel Başarıda & Evli & 241 & 2,012 & 0,843 & & \\
Düşme Hissi & Bekar & 119 & 3,561 & 0,843 & $-0,205$ & $\mathbf{0 , 0 4 1}$ \\
\hline
\end{tabular}
$\mathrm{p}<.05$

Tablo 3' e göre katılımcıların duygusal emek ile tükenmişlik ölçekleri alt boyutlarına katılımlarının medeni durum değişkenine göre anlamlı farklılık gösterip göstermediğini belirlemek amacıyla yapılan t-testi sonucunda grup ortalamaları arasinda; derinden rol yapma $(t=-2,276 ; p<0,05)$, doğal duygular $(t=-, 508 ; p<0,01)$ ve kişisel başarıda düşme hissi $(t=-0,205$; $\mathrm{p}<0,05)$ alt boyutunda anlamlı fark bulunmuştur. Bu fark evli katılımcılar lehinedir. 
Tablo 4. Antrenörlük Branş Türüne Göre Ölçek Alt Boyutlarının t Testi Sonucu

\begin{tabular}{|c|c|c|c|c|c|c|}
\hline \multicolumn{2}{|c|}{ Antrenörlük Branş1 } & $\mathrm{n}$ & Ort & Ss & \multirow{3}{*}{$\begin{array}{c}\mathrm{t} \\
0,457\end{array}$} & \multirow{3}{*}{$\frac{p}{0,161}$} \\
\hline Yüzeysel Rol & Takım sporları & 136 & 2,240 & 0,946 & & \\
\hline Yapma & Bireysel sporlar & 224 & 2,096 & 0,945 & & \\
\hline \multirow{2}{*}{$\begin{array}{c}\text { Derinden Rol } \\
\text { Yapma }\end{array}$} & Takım sporları & 136 & 3,952 & 0,852 & \multirow{2}{*}{2,655} & \multirow{2}{*}{0,008} \\
\hline & Bireysel sporlar & 224 & 3,681 & 1,070 & & \\
\hline \multirow{2}{*}{ Doğal Duygular } & Takım sporları & 136 & 4,304 & 0,750 & \multirow{2}{*}{0,799} & \multirow{2}{*}{0,425} \\
\hline & Bireysel sporlar & 224 & 4,237 & 0,790 & & \\
\hline \multirow{2}{*}{$\begin{array}{l}\text { Duygusal Tü- } \\
\text { kenme }\end{array}$} & Takım sporları & 136 & 2,215 & 0,702 & \multirow{2}{*}{2,320} & \multirow{2}{*}{0,021} \\
\hline & Bireysel sporlar & 224 & 2,038 & 0,703 & & \\
\hline \multirow{2}{*}{ Duyarsızlaşma } & Takım sporları & 136 & 2,116 & 0,854 & \multirow{2}{*}{2,421} & \multirow{2}{*}{0,016} \\
\hline & Bireysel sporlar & 224 & 1,902 & 0,790 & & \\
\hline \multirow{2}{*}{$\begin{array}{l}\text { Kişisel Başarıda } \\
\text { Düşme Hissi }\end{array}$} & Takım sporları & 136 & 3,677 & 0,719 & \multirow{2}{*}{0,260} & \multirow{2}{*}{0,963} \\
\hline & Bireysel sporlar & 224 & 3,681 & 0,810 & & \\
\hline
\end{tabular}

Tablo 4' e göre katılımcıların duygusal emek ile tükenmişlik ölçekleri alt boyutlarına katılımlarının antrenörlük branş türü değişkenine göre anlamlı farklılık gösterip göstermediğini belirlemek amacıyla yapılan t-testi sonucunda grup ortalamaları arasinda; derinden rol yapma $(\mathrm{t}=2,655$; $\mathrm{p}<0,05)$, duygusal tükenme $(\mathrm{t}=2,320 ; \mathrm{p}<0,05)$ ve duyarsızlaşma $(t=0,241$; $\mathrm{p}<0,05)$ alt boyutlarında anlamlı fark bulunmuştur. Bu fark takım sporcularını çalıştıran antrenörler lehinedir.

Tablo 5. Duygusal Emek Ölçeği Alt Boyutlan ile Tükenmişlik Ölçeği Alt Boyutlarn Arasinda Pearson Korelasyon Tablosu

\begin{tabular}{lccccccc}
\hline & & 1 & 2 & 3 & 4 & 5 & 6 \\
\hline 1- Yüzeysel Rol Yapma & $\mathrm{r}$ & 1 & & & & & \\
& $\mathrm{p}$ & & & & & & \\
2- Derinden Rol Yapma & $\mathrm{r}$ &, $241^{* *}$ & 1 & & & & \\
& $\mathrm{p}$ &, 000 & & & & & \\
3- Doğal Duygular & $\mathrm{r}$ &,- 027 &, $358^{* *}$ & 1 & & & \\
& $\mathrm{p}$ &, 605 &, 000 & & & & \\
4- Duygusal Tükenme & $\mathrm{r}$ &, 073 &,- 044 &,- 048 & 1 & & \\
& $\mathrm{p}$ &, 165 &, 401 &, 362 & & & \\
5- Duyarsızlaşma & $\mathrm{r}$ &, $147^{* *}$ &,- 029 &,$- 111^{*}$ &, $688^{* *}$ & 1 \\
& $\mathrm{p}$ &, 005 &, 588 &, 035 &, 000 & & \\
6- Kişisel Başarıda & $\mathrm{r}$ &,- 099 &, 087 &, $354^{* *}$ &,$- 155^{* *}$ &,$- 266^{* *}$ & 1 \\
Düşme Hissi & $\mathrm{p}$ &, 061 &, 101 &, 000 &, 003 &, 000 & \\
\hline
\end{tabular}


Tablo 5' e göre; yüzeysel rol yapma alt boyutu ile duyarsızlaşma alt boyutu pozitif yönde ve düşük düzeyde $(\mathrm{r}=, 147$; $\mathrm{p}<0,01)$; doğal duygular alt boyutu ile duyarsızlaşma alt boyutu arasında negatif yönde düşük düzeyde $(\mathrm{r}=-111 ; \mathrm{p}<0,05)$; doğal duygular alt boyutu ile kişisel başarıda düşme hissi alt boyutu arasında pozitif yönde ve orta düzeyde $(\mathrm{r}=, 354$; $\mathrm{p}<0,01)$ ilişki olduğu görülmektedir.

\section{Tartışma ve Sonuç}

Bulgulardan elde edilen sonuçlara göre; antrenörler en çok doğal duygu$\operatorname{lar}(\bar{x}=4,262)$ ile hareket etmekte, bunu derinden rol yapma $(\bar{x}=3,783)$ izlemektedir. Sonuncu sırada ise yüzeysel davranış $(\bar{x}=2,150)$ yer almaktadır. Bu sonuç, olumlu olarak değerlendirilmektedir. Çünkü, sporcusunu mesleki anlamda yetiştirme ve aynı zamanda davranışlarına yön verebilme becerisine/potansiyeline sahip olan antrenörlerin gerçekte hissettikleri duyguları ya özümseyerek ve içselleştirerek veya tamamen doğal olarak sergileyebilmeleri, onların yüzeysel ve samimiyetsiz davranmadıklarını göstermektedir. İçten duygu gösterimleri sporcular tarafından da olumlu olarak algılanacak ve samimi bir çalışma ortamı doğacaktır. Böyle bir atmosferde ise, sporcu ile etkileşim daha pozitif olacak, karşılıklı sevgisaygı ortaminda onların motivasyonunu ve verimini de olumlu yönde etkileyecektir.

Diğer taraftan tükenmişlik alt boyutları incelendiğinde duyarsızlaşma alt boyutunun $(\bar{x}=1,928)$ en düşük ortalamaya sahip olması, bunu duygusal tükenme $(\bar{x}=2,104)$ ile kişisel başarıda düşme alt boyutlarının $(\bar{x}=3,679)$ izlemesi ise şu şekilde yorumlanabilir. Doğal duygu gösterimlerinde bulunabilen antrenörler, sporcuları ile iyi bir etkileşim içindedirler ve onlara karşı negatif ve/veya duygusuz davranışlar mümkün olduğunca az göstermektedirler. Kişisel başarıda düşme alt boyutunun en yüksek ortalamaya sahip olması ise, araştırma kapsamında tükenmişlik davranışları incelenen antrenörlerin mesleklerine olan saygısını göstermesi açısından önemlidir. Çünkü duygusal emek harcarken mümkün olduğunca doğal ve içselleştirdikleri duyguları ile hareket etmekte, bu onlarda duyarsızlaşmaya neden olmamakta, fakat kendilerini meslekleri ile ilgili belki de mükemmeliyetçilik huyları sebebiyle düşük başarılı hissedebilmektedirler. 
Bunlara ek olarak; derinden rol yapma davranışının tükenmişlik ile istatistiki açıdan anlamlı düzeyde ilişkili olmaması; yüzeysel rol yapma davranışının düşük düzeyde de olsa duyarsızlaşma alt boyutu ile pozitif yönde ilişkili olması literatür bilgisi ile uyumludur. Kişilerin yapmacık davranışları, onların samimiyetsizliğini gösterir, bu ise mesleki duyarsızlık ile bağlantılıdır. Bununla paralel olarak doğal duygular duyarsızlaşma ile negatif yönde ilişkilidir. Doğal duygular tükenmişliğin alt boyutlarından kişisel başarıda düşme hissi alt boyutu ile pozitif yönde ilişkilidir. Literatürde araştırmamız ile benzerlik ve farklılık gösteren çalışmalar mevcuttur. Çalışmamızın bazı sonuçları, Kaplan ve Ulutaş (2016)' in çalışmasında bulduğu sonuçlara benzer niteliktedir. Duygusal emeğin tükenmişlik üzerindeki etkisini inceleyen araştırmalarında, yüzeysel davranış ile duygusal tükenme ve duyarsızlaşma arasında; derin davranış ile kişisel başarıda düşme hissi arasında pozitif yönlü ilişkiler olduğunu gösterdiğinden söz etmişlerdir. Başka bir çalışmada, Oral ve Köse (2011) yüzeysel davranışın çalışanların tükenmişlik düzeylerini artırdığı, iş doyumlarını ise azalttığl; derinden davranış ile tükenmişlik ve iş doyumu arasında ilişkinin olmadığı bulgusuna ulaşılmıştır. Ayrıca, kamu sektörü çalışanlarının daha fazla yüzeysel davranış sergiledikleri ve daha fazla duygusal çaba harcadıkları bulgusuna ulaşılmışlardır. Yüzeysel davranış duygusal tükenme ve duyarsızlaşma seviyelerini artırmaktadır, kişisel başarıda düşme duygusu ile yüzeysel davranış arasında ilişki ise bulunamamıştır. Derinlemesine davranış ile tükenmişlik arasında bir ilişki olmaması ise beklenen sonuç olarak değerlendirilmektedir. Derin davranış, empati içerikli ve karşısındakini anlamaya yönelik bir davranış biçimidir. Dolayısıyla, derin davranış ile duyarsızlaşma arasında bir ilişkinin bulunmaması da olağan karşılanmaktadır (Oral ve Köse, 2011). Bir başka araştırmada ise, yüzeysel rol yapma işgücü devir hızı ve duygusal tükenme ile doğrudan ilişkilidir, derinden rol yapma ise bizim çalışmamızda olduğu gibi söz konusu değişkenler ile ilişkili çıkmamıştır (Goodwin vd, 2011). Otel çalışanları üzerinde yapılan bir diğer araştırmada derinden rol yapma tükenmişlik seviyesine pozitif katkı yapmamışken, yüzeysel davranış yapmıştır. Bu ise, yüzeysel davranışın duygusal tükenme ile daha çok ilişkili olduğu şeklinde yorumlanabilir (Kim, 2008). 
Duygusal emek kavramının işe bağlılık, duygusal zeka, iş performansı, kişilik özellikleri ile ilişkisini araştıran çalışmalarda ise, bizim çalışmamıza benzer şekilde, duygusal emek alt boyutlarından pozitif olanların (derinden rol yapma ve doğal davranışlar), pozitif örgütsel değişkenler (işe bağlllık, sorumluluk sahibi olma, iş tatmini gibi) ile ilişkisinin yine pozitif, olduğu görülmektedir. Diğer taraftan, negatif (yüzeysel rol yapma) olan alt boyutun ise negatif örgütsel değişkenler (işten ayrılma niyeti gibi) ile pozitif yönde ilişkide olduğu görülmektedir. Tükenmişlik değişkeni de negatif bir örgütsel değişken olarak pozitif örgütsel değişkenler ile negatif yönde ilişkilidir. Kahramanmaraş il merkezinde belediye çalışanları üzerinde yapılan bir araştırmaya göre; yüzeysel davranışın iş tatmini üzerinde herhangi bir etkiye sahip olmadığı; ancak işten ayrılma niyetini ve duygusal tükenmişliği pozitif yönde etkilediği görülmüştür. Derinlemesine davranış ise, işten ayrılma niyeti ile duygusal tükenmişlik üzerinde herhangi bir etkiye sahip değildir (Yeşil ve Mavi, 2018).

Bir başka araştırma, üniversitelerin öğrenci işlerinde çalışan memurlar üzerinde yapılmıştır; duygusal emek davranışlarından doğal davranma ve derinden davranma ile işe bağlllık arasında anlamlı bir ilişki bulunmuştur. Ayrıca, yüzeysel davranış ile işe bağlılık arasında da beklenenin aksine pozitif yönlü ilişki görülmüştür (Gülova vd, 2013:68). Özel güvenlik görevlileri üzerinde yapılan başka bir araştırmaya göre; duygusal zeka düzeyinin yüksek olması, çalışanın derinden davranış alt boyutu ve doğal duygular alt boyutuna katılımını artırmakta, yüzeysel davranışı ise azaltmaktadır. Başka bir deyişle, duygusal zekası yüksek olan bireyler sergilemeleri gereken rolleri ya gerçekten içselleştirmektedirler veya o duyguları doğal olarak hissetmektedirler. Duygusal emek stratejilerinin işe tükenmişlik üzerinde anlamlı bir etkisinin olmadığı görülmüştür. Diğer bir yorumla, duygusal zeka ile duygusal emek stratejilerinden elde edilen sonuçlar birbirini destekler niteliktedir. Yüksek duygusal zeka derinlemesine davranış ve doğal duyguların oluşumunu, tükenmişliğin ise azalmasını sağlamaktadır. Araştırmanın en önemli sonucu budur. Özellikle hizmet sektörü çalışanlarının yaşadıkları tükenmişliği en aza indirebilmek için, işlerinde sergilemek zorunda oldukları davranışları ya işlerinin bir gereği olarak görüp geçici bir maske takmaları gerektiğini özümseyip ona göre davranmaları gerekmektedir. Sergilemek zorunda 
oldukları duyguları samimi bir şekilde içselleştirmeleri onların tükenmişlik yaşamalarını engelleyecektir(Polatcı ve Özyer, 2015).

Diğer bir araştırmada; Ankara' da özel hizmet sektörü çalışanları üzerinde, duygusal emeğin iş performansı ve işten ayrılma niyetine etkisinde kişilerarası çarpıklığın aracılık rolü incelenmiştir. Kişiler arası çarpıklık, duygusal emeğin tüm alt boyutları ile iş performansı arasında anlamlı olarak aracılık ederken, duygusal emeğin sadece yüzeysel rol yapma alt boyutu ile işten ayrılma niyeti arasında kişiler arası çarpıklığın aracılık etkisi anlamlı olduğu sonucuna ulaşılmıştır (Beğenirbaş ve Çalışkan, 2014). Banka çalışanları üzerinde yapılan bir araştırmada duygusal emek ve iş performansları arasındaki ilişki incelenmiştir. Yüzeysel rol yapmanın iş performanslarını azalttığı, doğal duygularını sergileyebilenlerin iş performanslarının arttığ gözlenmiştir. Derinden rol yapma ise iş performansı ile ilişkili bulunmamıştır (Beğenirbaş ve Turgut, 2014). Mengenci'nin (2015) hizmet sektörü çalışanları üzerinde yaptığı araştırmasına göre ise, iş tatmini yüksek olan çalışanların daha çok derinden rol yapma ile doğal duygular sergiledikleri, yüzeysel rol yapmayı ise daha az tercih ettikleri sonucuna ulaşmışlardır. Diğer taraftan, tükenmişlik yaşayan çalışanların daha çok, yüzeysel davranış sergilemesi söz konusudur.

Akademisyenler üzerinde yapılan bir araştırmada; kişilik özelliklerinden sorumluluk özelliğine sahip akademisyenlerin derinlemesine duygusal emek gösterimlerinin yüksek olduğu sonucuna ulaşılmıştır. Sorumluluk özelliğine sahip olan ademisyenler çalışma sırasında göstermeleri gereken duygusal çabayı rahatlıkla sergilemekte ve duygusal uyum içinde hareket etmektedirler. Çünkü sorumluluk özelliğine sahip akademisyenler yapıları gereği, amaca yönelik planlama yapan ve görev bilinci ile hareket eden kişilerdir. Kurumların kendilerine yükledikleri misyonu rahatlıkla ve özveri ile kabul edip, yapıları gereği olumsuz duygulardan uzak durarak duygu ve davranışlarını kolaylıkla uyumlandırabilirler. Akademisyenlerin duygusal denge kişilik özelliğine sahip olmaları, onların daha güçlü empati kurmalarına yol açarak derinlemesine duygusal emek gösterimlerini artırmaktadır. Onların dengelilik hali sergilemesi, kendilerinden duygu gösterimlerini endişe ve kaygıdan arınmış bir şekilde, rol yaparak değil derinden hissederek ve uyum içinde ser- 
gilemelerini sağlamaktadır. Genel olarak bakıldığında pozitif kişilik özelliğine sahip olan akademisyenler, yüzeysel duygusal emek gösterimlerini düşürmekte ve gerçekte hissetmedikleri duyguları göstermeye çalışmamaktadırlar (Güler ve Marşap, 2018).

Otel çalışanları üzerinde yapılan ve lider-üye etkileşimin tükenmişlik üzerindeki etkisini ölçmeyi amaçlayan bir araştırmada, lider-üye etkileşim kalitesine göre tükenmişlik düzeyinin değiştiği ortaya konulmuştur. Başka bir deyişle, lider ile etkileşimi daha iyi olanlar daha az tükenmişlik yaşamaktadırlar (Bolat, 2011:7). Bir başka araştırmada ise; derin davranış ile iş yükü arasında negatif yönlü ilişki vardır. İşs stresi arttıkça tükenmişlik ve duygusal emek düzeyi de artmaktadır. Ayrıca, duygusal emeğin iş stresi ve tükenmişlik arasında düşük düzeyde de olsa aracı bir rol oynadığı söylenebilir (Akdu ve Akdu, 2016).

Araştırmamızda demografik değişkenlerin duygusal emek ve tükenmişlik üzerinde anlamlı fark yaratıp yaratmadığı incelendiğinde ise medeni durum değişkeninin derinden rol yapma ve doğal duygular üzerinde anlamlı fark yarattığı, farklılığın ise evli katılımclar lehine olduğu görülmektedir. Araştırma bu sonucu itibariyle, evliliğin kişinin duygu gösterimlerinde yaratabildiği farkı vurguladığ 1 için anlam ve önem kazanmaktadır. Evlilik, çiftlerin ve bir aile ortamında bireylerin birbirleri ile uyum içerisinde yaşayabilmeleri için empati yapmalarını gerekli kılar. Karşısındakini anlayabilen birey, duygu gösterimlerinde yüzeysel değil, derinden ve doğal davranacaktır. Bu davranışları kazanabilen bireyler, bunları hayatının geneline yaygın şekilde kullanabilme yeteneği kazanacak, iş hayatında yansımaları da olumlu olacaktır. Çalışmamızda, evli antrenörlerin derinden rol yapma ve doğal duygular ile hareket edebilme düzeylerinin bekarlara kıyasla daha yüksek düzeyde olması bu şekilde yorumlanmaktadır. Literatürde çalışmamızdan farklı olarak; demografik değişkenlere göre duygusal emek ve tükenmişlik ölçeklerine katılımın farklılaşmadığını ortaya koyan çalı̧̧malar mevcttur. Bayram ve ark (2012) hizmet sektöründe görev yapan çalışanlar üzerinde duygusal ve tükenmişlik inceledikleri çalışmalarında cinsiye değişkenine göre ölçeklere katılımın anlamlı fark yaratmadığ ${ }_{1}$ bulgusuna ulaşmışlardır. Oral ve Köse (2011) de araştırmaları sonucunda; cinsiyet, medeni durum, kıdem, yaş gibi demografik özelliklere bağlı olarak duygusal emek boyutlarında herhangi bir farklılığın gözlenmediğini belirtmişlerdir. 
Sonuç olarak; derinden rol yapma davranışını artırabilmek için empati seviyesinin yüksek tutulması sağlanmalıdır. Duygusal emek harcanmasının yarattığı psikolojik erozyonu önleme için motivasyon temelli uygulamalara yer verilmelidir (Güler ve Marşap, 2018). Ayrıca; antrenörlük mesleğinin gereklerinden olan duygusal emeğin antrenör üzerinde olumsuz etkilerini en aza indirgeyebilmek için gerekli kurumsal tedbirler alınmalıdır. Onların sporun en önemli aktörlerinden olduğu göz ardı edilmemelidir. Özlük hakları ile çalışma koşulları ne kadar iyi olursa verimleri de o kadar iyi olacaktır. Huzurlu bir çalışma ortamı içesinde fedakarlık yapma istekleri de daha fazla olacak ve gerçekten hissettikleri duygular ile görevlerini ifa edebileceklerdir. Bu ise tükenmişlik duygularını mümkün olduğunca aza indirecektir.Araştırma grubunu çeşitli illerdeki gençlik spor ve il müdürlüğü çalışanları oluşturmaktadır. Araştırmanın özel sektörde görev yapan antrenörlere de yapılması sonuçların karşılaştırılabilmesini sağlayacaktır. Özel sektörde ödenen ücretlerin daha değişken olması, sağlanan sosyal hakların kamu kurumlarındaki gibi belli bir standart arz etmemesinin, sonuçları etkileyebileceği düşünülmektedir. 
EXTENDED ABSTRACT

\title{
Analysis of the Correlation Between Emotional Labour and Burnout in Coaches
}

\author{
* \\ Sevim Güllü - Sülayman Şahin \\ İstanbul-Cerrahpaşa University - Uludağ University
}

Each profession has its own characteristics, and the emotions / behaviours of individuals who execute that profession generally possess similar qualities as well. Just like the teacher has a direct impact on the students' academic achievements, the coach profession has a direct effect on the athletes' success in sports.

Emotional labour is defined as the employee exhibiting the desired feelings by the organization. The concept of emotional labour is examined in three sub-dimensions. Superficial acting can be defined as the person pretending as if he feels the emotions that he does not feel. Individuals do not change their true emotions but control their expression of emotions; they react as expected, in other words they do not change their feelings in reality, the purpose is to fulfill what the organization wants from them. Deep acting; unlike the superficial acting concept, it is the employee's attempt to truly feel the desired emotion, and is the adaptation of not only the behaviours but also the emotions to the rules of conduct. Even if the emotions that a person has to show and the emotions he wants to show differ from each other, first, the person chooses to change his emotions and to follow the conditions, thus, natural harmony occurs between emotions and behaviours. Natural emotions; is the employee expressing his emotions as he likes without too much emotional labouring and feeling an obligation.

Burnout; is the individual feeling that energy resources are decreasing as a result of negative conditions and experiences. It is examined in three dimensions. Emotional burnout; is the most basic component of burnout syndrome. The fact that the person is exhausted both physically and emotionally is the state in which the emotional resources of the person are 
overloaded and finished. Depersonalization; is the concept that expresses being negative, emotionless or overreacting towards the ones being served. Sense of decline in the personal achievement; can be defined as the person believing that his proficiency and efficiency is declining. The burnout process emerges as a response to stress-related stress sources that consume one's emotional resources and it first begins with emotional exhaustion. The employee, together with the emotional exhaustion, chooses to cut his ties with others and put a psychological distance to his relationship with others as a coping strategy. When depersonalization occurs, the individual notices the discrepancy between his current situation and the expectations of the organization, which leads to a sense of decline in personal achievement.

Since emotional labour is the management of emotions and behaving accordingly, research on the subject is more focused on the relationship between the emotional labour and the employee's attitudes and behaviours. Although emotional labouring leads to positive outcomes such as increased productivity in the organization or an increase in service quality and an increase in customer satisfaction, the employees' job dissatisfaction can lead to burnout, psychological and physiological disturbances and alienation. Burnout is seen as one of the most significant and most important outcomes of emotional labouring.

The aim of this research is to reveal the level of correlation between the coaches' emotional labour and their burnout.

\section{Method}

\section{The Research Model}

In this study, descriptive and relational surveying model was used as the research technique.

\section{Study group}

The study group consists of 360 olympic sports branches coaches, 89 female and 271 male, selected by convenience sampling method of non-random sampling methods. In order to reach the findings, the participants 
were asked to provide their demographic information and two different scales were applied.

Emotional Labour Scale: The scale was developed by Diefendorff et al. (2005), Grandey (2003) and Kruml and Geddes (2000). Basım and Beğenirbaş (2012) adopted some items of the scale to Turkish and they made the validity-reliability study and brought it into the literature. It consists of three sub-dimensions, superficial acting, deep acting and natural emotions, and a total of 16 statements. A 5-point Likert type scale stretching between 1 (Almost never) and 5 (Almost always) was used.

Burnout Scale: It was developed by Maslach and Jackson (1981) and adapted to Turkish by Ergin (1992). It consists of 22 questions and three dimensions. It was directly copied from Sevim (2011)'s study. The scale consists of 22 items and 3 sub-scales, including emotional exhaustion, depersonalization, and sense of decline in personal achievement.

\section{Conclusion}

According to the results obtained from the findings, the coaches mostly act with natural emotions, this is followed by deep acting). The last one is superficial behaviour. This result is considered to be positive. Because, the fact that coaches who have the ability / potential to train their athletes professionally and also to direct their behaviours, internalize the emotions they feel in reality or exhibit them completely naturally show that they are not superficial and insincere. Sincere emotions will be perceived as positive by athletes and this will lead to a friendly working environment. In such an atmosphere, interaction with the athlete will be more positive, and this will positively affect their motivation and efficiency in an environment of mutual love-respect.

When the burnout sub-dimensions are examined, the fact that the depersonalization sub-dimension has the lowest mean; and this being followed by the emotional exhaustion and decline in personal achievement sub-dimensions can be interpreted as follows. Coaches who are able to show natural emotions to the athletes interact well with them; and they show as little negative and emotionless behaviours as possible towards 
them. The decline personal achievement sub-dimension having the highest average is important because it shows the respect the coaches, whose burnout behaviours were examined within the scope of the research, have for their profession. Because while emotional labouring, they try acting natural and show their internalized emotions. This does not cause depersonalization for them, however, they may feel less successful about their profession, perhaps because of their perfectionist behaviour.

In addition to these, the fact that deep acting behaviour does not have a statistical and significant correlation with burnout; the fact that superficial acting behaviour is positively correlated with the depersonalization sub-dimension is consistent with the literature. People's unnatural behaviours show their insincerity, and this is linked to professional insensitivity. Parallel to this, natural emotions are negatively correlated with depersonalization. Natural emotions are positively correlated with the sub-dimensions of burnout and the sense of decline in personal achievement.

In conclusion, it was determined that there is a correlation between the emotional labor levels and burnout levels of the coaches surveyed within the scope of the research, working in Olympic sports branches.

\section{Kaynakça / References}

Akdu, U., ve Akdu, S. (2016). Duygusal emek ve iş stresinin tükenmişlik üzerindeki etkileri: Profesyonel turist rehberleri üzerinde bir araştırma. Journal of International Social Research, 9(47), 1142-1153.

Ashforth, B.E., Humprey, R.H. (1993). Emotional labor in service roles: The influence of identity. Academy and management journal, 18, 88115.

Basım, H. N., ve Beğenirbaş, M. (2012). Çalışma yaşamında duygusal emek: Bir ölçek uyarlama çalışması. Yönetim ve Ekonomi: Celal Bayar Üniversitesi İktisadi ve İdari Bilimler Fakültesi Dergisi, 19(1), 7790.

Bayram, N., Aytac, S., ve Dursun, S. (2012). Emotional labor and burnout at work: a study from Turkey. Procedia-Social and Behavioral Sciences, 65, 300-305. 
Begenirbaş, M., ve Çalışkan, A. (2014). Duygusal emeğin iş performansı ve işten ayrılma niyetine etkisinde kişilerarası çarpıklığın aracılık rolü. Business and Economics Research Journal, 5(2), 109-127.

Begenirbaş, M., ve Turgut, E. (2014). İş performansının sağlanmasında çalışanın duygusal emeğinin ve örgütte güven algısının etkileri. ISGUC The Journal of Industrial Relations and Human Resources, 16(3), 131-149.

Begenirbaş, M., ve Yalçın, R. C. (2012). Öğretmenlerin kişilik özelliklerinin duygusal emek gösterimlerine etkileri. Cag University Journal of Social Sciences, 9(1), 47-66.

Bolat, O. İ. (2011). Lider-üye etkileşimi ve tükenmişlik ilişkisi. “İ̧̧ Güç” Endüstri İlişkileri ve İnsan Kaynakları Dergisi,. 13(2), 63-80.

Brotheridge, C. M., Grandey, A. A. (2002). Emotional labor and burnout: comparing two perspectives of 'People Work'. Journal of Vocational Behavior, 60, 17-39.

Diefendorff, J.M., Croyle, M.H., Ve R.H. Grosserand. (2005). The dimensionality and antecedents of emotinal labor strategies. Journal of Vocational Behavior, 66, 339-357

Eroğlu, Ş. G. (2014). Örgütlerde duygusal emek ve tükenmişlik ilişkisi üzerine bir araştırma. Pamukkale Üniversitesi Sosyal Bilimler Enstitüsü Dergisi, 19, 147-160.

Ergin, C. (1992). Doktor ve hemşirelerde tükenmişlik ve maslach tükenmişlik ölçeğinin uyarlanması. VII. Ulusal Psikoloji Kongresi Bilimsel Çalışmaları, 22-25 Eylül 1992, Hacettepe Üniversitesi, VII. Ulusal Psikoloji Kongresi Düzenleme Kurulu ve Türk Psikologlar Derneği Yayını, Ankara.

Goodwin, R. E., Groth, M., \& Frenkel, S. J. (2011). Relationships between emotional labor, job performance, and turnover. Journal of Vocational Behavior, 79(2), 538-548.

Grandey, A. (2003). When the show must go on: Surface acting and deep acting as determinants of emotional exhaustion and peer-rated service delivery. Academy of Management Journal, 46, 86-96.

Güler, H. N., ve Marşap, A. (2018). Kişilikle duygusal emek ilişkisi: Akademisyenler üzerinde bir araştırma. Avrasya Sosyal ve Ekonomi Araştırmaları Dergisi, 5(12), 154-173. 
Gülova, A. A., Palamutcuoğlu, B. T., ve Palamutcuoğlu, A. T. (2013). Duygusal emek ile işe bağlılık arasındaki ilişkide amir desteğinin rolü: Üniversitede öğrenci işleri personeline yönelik bir araştırma. Dokuz Eylül Üniversitesi İktisadi ve İdari Bilimler Fakültesi Dergisi, 28(2), 41-74.

Kaplan, M., ve Ulutaş, Ö. (2016). Duygusal emeğin tükenmişlik üzerindeki etkisi: otel işletmelerinde bir araştırma. Selçuk Üniversitesi Sosyal Bilimler Enstitüsü Dergisi, 35, 165-174.

Kim, H. J. (2008). Hotel service providers' emotional labor: The antecedents and effects on burnout. International Journal of Hospitality Management, 27(2), 151-161.

Kruml, Susan M. ve Deanna Geddes. (2000). Exploring the dimensions of emotional labor the heart of hochschild's work. Management Communication Quarterly, 148(1), 8-49.

Lewin, J.E. ve Sager, J.K. (2007). A Process Model of Burnout Among Salesperson: Some New Thoughts. Journal of Business Research, 60, 1216-1224.

Maslach, C .ve Jackson, S.E. (1981). The measurement of experienced burnout. Journal of Occupational Behaviour, 2, 99-113.

Mengenci, C. (2015). İş tatmini, duygusal emek ve tükenmişlik ilişkilerinin belirlenmesi. Ege Akademik Bakı̧, 15(1), 127-139.

Oral, L., ve Köse, S. (2011). Hekimlerin duygusal emek kullanımı ile iş doyumu ve tükenmişlik düzeyleri arasındaki ilişkiler üzerine bir araştırma. Süleyman Demirel Üniversitesi İktisadi ve İdari Bilimler Fakültesi Dergisi, 16(2), 463-492.

Polatc1, S., ve Özyer, K. (2015). Duygusal emek stratejilerinin duygusal zekanın tükenmişliğe etkisindeki aracılık rolü. Abant İzzet Baysal Üniversitesi Sosyal Bilimler Enstitüsü Dergisi. 15(3), 131-156.

Sevim, L. (2011). Tükenmişlik ve işe bağlılığın örgütsel vatandaşlık davranışı üzerindeki etkisi: Turizm sektöründe bir araştırma. Hacettepe Üniversitesi. Ankara

Tunç, P., Gitmez, A., ve Boothby, K.R. (2014). Yoğun bakım ve yataklı servis hemşirelerinde duygusal emek stratejilerinin empatik eğilim açısından incelenmesi. Anatolian Journal of Psychiatry/Anadolu Psikiyatri Dergisi, 15(1), 45-54. 
Yeşil, S. ve Mavi, Y. (2018). Duygusal emeğin etkilediği faktörler üzerine bir alan araştırması. Aksaray Üniversitesi İktisadi ve İdari Bilimler Fakültesi Dergisi, 10(1), 29-44.

Yilmaz, K., Altinkurt, Y., Guner, M., ve Sen, B. (2015). The relationship between teachers' emotional labor and burnout level. Eurasian Journal of Educational Research, 59, 75-90.

Yürür, S., ve Ünlü, O. (2011). Duygusal emek, duygusal tükenme ve işten ayrılma niyeti ilişkisi. ISGUC The Journal of Industrial Relations and Human Resources, 13(2), 81-104.

\section{Kaynakça Bilgisi / Citation Information}

Güllü, S. ve Şahin, S. (2019). Antrenörlerde duygusal emek ve tükenmişlik ilişkisinin incelenmesi. OPUS-Uluslararası Toplum Araştırmaları Dergisi , 10(17), 332-354. DOI: 10.26466/opus.515620 